УДК 94(100-87)+929Черчилль

БУРАКОВ Ю.В.

https://orcid.org/0000-0001-7180-4469

ПИТЛЬОВАНА Л.Ю.

https://orcid.org/0000-0002-5700-9992

https://doi.org/10.33577/2313-5603.35.2021.291-301

\title{
«БЕЗКОМПРОМІСНИЙ ГЕНІЙ»: ЩЕ РАЗ ПРО РОЛЬ ПРИНЦИПІВ У ПОЛІТИЦІ
}

Джконсон Б. (2019). Фактор Черчилля. Як одна людина змінила історію, пер. $з$ англ. Ю. Гірича. Харків: Віват, 400 с.

Вихід друком у 2019 р. праці політика, журналіста і чинного прем’єр-міністра Великої Британії Бориса Джонсона «Фактор Черчилля. Як одна людина змінила історію» в українському перекладі Юрія Гірича стало помітною подією на вітчизняному книжковому ринку. Написана 2014 року книга $\epsilon$ не перша у творчому доробку автора, але, безумовно, найбільш резонансна i обговорювана у світі.

Борис Джонсон (Alexander Boris de Pfeffel Johnson) народився 1964 р. i, як і герой його книги, прийшов у політику через журналістику. На шляху до вершини владного Олімпу він обіймав посади мера Лондона (2008 - 2016), міністра закордонних справ (2016 2018). Депутат палати громад від консерваторів, 32019 р. він стає офіційним лідером партії й одним із лідерів кампанії за вихід Великої Британії з Європейського Союзу (ЄС).

Книга Бориса Джонсона зовсім не є черговою біографією видатного британського політичного діяча Вінстона Черчилля, кількість яких обчислюється десятками. Це, радше, роздуми практикуючого політика, переконаного консерватора, про людину, яка $\epsilon$ його кумиром, i значення якої, як видно 3 назви книги, важко переоцінити. Автор рецензованої книги зазначає: «Чудово розумію, що про нашого героя щороку з’являються сотні

Бураков Юрій Васильович, кандидат історичних наук, доцент, провідний науковий співробітник Наукового центру Сухопутних військ Національної академії сухопутних військ імені гетьмана Петра Сагайдачного, м. Львів.

Питльована Лілія Юріївна, кандидат історичних наук, дочент, доцент кафедри історї̈ Українського католицького університету, м. Львів.

(С) Бураков Ю. В., Питльована Л. Ю., 2021 
нових книжок, а проте, я певен, настав час на свіжий погляд, оскільки в нас немає права знехтувати репутацією такої особистості. Його видатна персона $є$ яскравим спростуванням усіх тих марксистських теорій, згідно 3 якими лінія історії формується якимись глобальними й безликими економічними силами. Сутністю фактора Черчилля $є$ те, що одна людина може змінити все» (c.11-12).

Важливо зазначити, що хоча Борис Джонсон і не є фаховим істориком, він написав свою книгу на основі широкої джерельної бази. Серед раніше не опублікованих історичних джерел - документи iз національних архівів прем'єр-міністра (Prime Minister's papers (PREM)), парламенту (House of Commons Debates), кабінету міністрів (Cabinet papers (CAB), особистих документів Черчилля. Докладно аналізуються щоденники, мемуари, збірки документів, існуюча історична література, навіть історичні карикатури та анекдоти про колишнього лідера Великої Британії. Досить повно представлена бібліографія основних праць Вінстона Черчилля, хронологія основних подій його діяльності.

Вже у вступі Б. Джонсон досить однозначно декларує свою оцінку особи В. Черчилля як «безкомпромісного генія» (с. 10) і на наступних чотирьохсот сторінках книги так чи інакше переконує у цьому й читача. Це зовсім не означає, що книга $є$ чистою апологетикою великого Черчилля, зовсім ні. Автор показує нам його, перш за все, живою людиною, часом суперечливою, часом ексцентричною та екстравагантною, неординарною, іноді аж до геніальності.

Б. Джонсон щедро підкреслює різноманітні таланти свого героя. Перед нами постає Черчилль-журналіст, Черчилль-письменник (Джонсон неодноразово згадує про Нобелівську премію Черчилля в галузі літератури 1953 р. і вступає у полеміку з іï критиками), Черчилль-оратор («...слова Черчилля збадьорювали людей, розправляли їм крила, заряджали енергією та силою» (с. 104); «Гітлер продемонстрував те зло, якого можна досягти засобами риторичного мистецтва. А Черчилль показав, як тим самим людство врятувати» (с. 109), Черчилль-«найвеличніший державний діяч 3 усіх, кого породила Британія» (с. 7). Джонсон захоплюється його феноменальною пам'яттю, колосальною енергією, гострим аналітичним розумом, креативністю.

Але Черчилль Бориса Джонсона - це не святий безгрішний праведник. Автор не заперечує, що поза державними інтересами, він відзначався і цілком людськими слабостями: жагою слави та визнання, страхом осоромитися перед громадськістю (с. 205). 
Це політик, який разом 3 гучними перемогами робив і чимало помилок, ціна яких іноді була дуже високою, і якими й досі йому дорікають, як от, наприклад, Галліполійська кампанія 1915 р. (Дарданельська операція). Військові і політичні промахи В. Черчилля цілеспрямовано не оминаються у книзі. Автор навіть спеціально акцентує на них, але 3 метою ще раз проаналізувати їх, пояснити читачеві, чому в певних конкретно-історичних обставинах були прийняті ті чи інші рішення, і якими були їх наслідки.

Дослідження Бориса Джонсона складається з 23 розділів. Він свідомо відходить від традиційного хронологічно-послідовного викладу історії життя і діяльності видатного британського політика, характерного для більшості біографічних праць. Структурування показує, який етап життя і діяльності Вінстона Черчилля автор вважає поворотним моментом, причому не лише у біографії героя, а й Європи та людства загалом. Перший розділ під назвою «Пропозиція Гітлера» підкреслює, що саме безкомпромісність позиції Черчилля щодо Гітлера та ідеології нацизму стала запорукою досягнення Великої Перемоги у 1945 р. Ця ідея є наскрізною у рецензованій книзі.

Розповідь Джонсона розпочинається 3 опису засідання Воєнного кабінету Великої Британії 28 травня 1940 р., ключовим питанням порядку денного якого було питання, чи варто Британії ставати до боротьби 3 нацистською Німеччиною. Попри офіційне проголошення війни певні політичні кола все ще вели закулісні перемовини між Лондоном і Берліном, і все ще існував шанс за посередництвом Риму досягти компромісу.

У ті дні Велика Британія залишилася на самоті із загрозою нацистського вторгнення. Гітлер вже окупував більшу частину Західної Свропи. Лідер фашистської Італії Б. Муссоліні мав невдовзі приєднатися до війни («Сталевий пакт»), більшовицький вождь Й. Сталін поділив із А. Гітлером Східну та Південну Європу (пакт Молотова - Ріббентропа), США ще дотримувалися політики «ізоляціонізму», невтручання у європейські справи.

Непохитна позиція Черчилля щодо «примиренців» Н. Чемберлена, лорда Галіфакса та інших впливових політиків втримала Британію від фатальної помилки - піти на угоду з Гітлером. «Чимало хто вважав, що приниження своєї гідності є допустимою ціною за збереження імперії та запобігання кровопролиттю. Не те щоб люди бажали угоди з Гітлером - багато хто вважав іiі неминучою» (с. 30). «Він (Черчилль - Ю.Б., Л.П.) був готовий 
заплатити кров'ю, тому що справді бачив суть чіткіше, ніж Галіфакс. Він мав величезну і майже відчайдушну відвагу, щоб усвідомити: війна - це жах, але підкорення - ще гірше» (с. 27).

Пригадаймо, що вже у славнозвісній промові В. Черчилля у Палаті громад від 13 травня 1940 р., першій на посаді прем’єрміністра, він закликав до боротьби проти жахливої тиранії, злочини якої безпрецедентні, i заявляв, що не може обіцяти народу Британії нічого, крім крові, важкої праці, сліз і поту, тому що це єдиний шлях до перемоги, а будь-який інший результат це крах виплеканої попередніми поколіннями мрії про краще майбутнє для людства.

Автор показує нам Другу світову війну очима британця, європейця, і ця картинка не завжди збігається 3 нав'язаною нам ще радянською історіографію та пропагандою часів СРСР. Джонсон переконливо демонструє визначну роль британського прем'єра в організації збройного опору нацистській агресії у перші роки Другої світової війни, його зусилля зі створення Антигітлерівської коаліції, які врешті-решт спричинилися до перемоги над німецьким нацизмом та японським мілітаризмом.

«Я завжди з осторогою ставився до історії «альтернативної»пише Борис Джонсон, - оскільки розумію, що так званий причиново-наслідковий ланцюжок ніколи не $є$ достеменно пізнаваним... Витягніть один зі жмені чинників - і ніколи не вгадаєте, як стане решта. А проте з усіх можливих історичних «а якби» ця гіпотеза певно, найвідоміша. Деякі з-поміж найкращих сучасних істориків вдалися до такого моделювання, і переважна більшість їхніх висновків свідчить про одне: якби в 1940 році Британія припинила чинити опір, це створило би передумови для непоправної катастрофи в усій Свропі» (с. 31). Важко не погодитися $з$ цим твердженням автора.

На сторінках книги він ще неодноразово вдається до таких «уявімо» і «якби», даючи читачеві повнішою мірою зрозуміти наслідки тих чи інших рішень В. Черчилля, твердість його моральних і світоглядних принципів, які допомогли Великій Британії вистояти у цей, за словами короля Георга VI, «скорботний час, мабуть найфатальніший у нашій історії» (промова від 3 вересня 1939 р.).

Теза про вірність Вінстона Черчилля своїм принципам наскрізною ниткою проходить через усі розділи книги. Про який період життя i 
діяльності героя не розповідав би Борис Джонсон, він незмінно наголошує, що принциповість, непідкупність, мужність і відвага у відстоюванні своїх переконань - найважливіша риса британського прем'єра, основа його морального духу і політичної величі.

У подальших розділах книги автор аналізує родинну історію Черчилля, становлення його як людини, офіцера, журналіста i політика. Відносини з батьками відіграли важливу роль у формуванні особистості та характеру Вінстона (с. 39 - 62). Джонсон показує непересічний, хоча і неоднозначний (в тому числі психологічний) вплив, який мав на сина Рендольф Черчилль. Ставши в юності свідком політичного колапсу батька, Вінстон у період дорослішання усіма силами намагався довести, що він - гідний син i реабілітувати самого батька. Особливої підтримки не було і від ніжно любимої ним матері, яка завжди була далекою, не доступною, холодною. «Батьки його, - робить висновок Б. Джонсон, були по-своєму настільки ж самовільні й нестандартні, як він. I їхнім найважливішим внеском (в історію - Ю.Б., Л.П.) є те, що вони обоє недбало виховували свою дитину» (с. 49).

Такі риси характеру, як честолюбство, амбітність, егоцентризм, цілеспрямованість, сміливість, створювали для молодого Вінстона передумови для досягнення виняткових результатів спочатку у військовій справі та журналістиці. Згодом величезна працездатність, психологічна стійкість та високий інтелект створили передумови для успіху і в політичній кар'єрі. Борис Джонсон намагається розібратися у тому, що спонукало молодого Черчилля 3 ризиком для власного життя брати активну участь у колоніальних війнах, які на той час вела Велика Британія на чотирьох континентах земної кулі.

Почавши службу лейтенантом, Черчилль встиг під час п'ятимісячної відпустки взяти участь у іспано-американській війні за острів Куба 1898 р. У результаті своєї першої військової кампанії молодий Вінстон отримав іспанську медаль за участь у бойових діях і заробив перший гонорар за серію статей 3 театру війни, розміщених в англійській пресі. Після цього він взяв участь у складі експедиції з придушення повстання одного з племен на північно-східному кордоні Малакандського перевалу в Індії. Далі він вирушив на війну в Африку, у Судан і яскраво описав жорстокості війни та дії експедиційного корпусу на чолі 3 генералом Г. Кітченером у творі «Річкова війна». 
Як тільки спалахнула англо-бурська війна, Черчилль вирушив до Південної Африки. Але вже не як військовий, а як кореспондент газети «Морнінг пост». Під час воєнних дій він потрапив у полон до бурів і мало не був розстріляний. Черчилля врятувало те, що його впізнали і вирішили залишити як цінного бранця, сина англійського лорда. Вінстону вдалося втекти 3 полону i, на короткий час, стати героєм британської громадської думки.

Праці В. Черчилля про всі ці події, пише Б. Джонсон, більше схожі на вікторіанські пригодницькі романи: це «бадьоре, пробивне, сповнене коротких речень у дусі «бах-бабах»» чтиво, яке змушує читача ковтати сторінку за сторінкою. Вінстонові вдавалося зображати батальні сцени краще за багатьох тогочасних майстрів художнього слова, до того ж він мав ще одну беззаперечну перевагу: «він міг оповідати від першої особи» (с. 84).

Б. Джонсон докладно описує діяльність В. Черчилля у роки Першої світової війни. Він зустрів їі вже досвідченим офіцером і політиком. Автор книги намагається бути максимально об'єктивним і показує не лише стратегічний талант свого героя, а й прорахунки, які насамперед пояснює його високими амбіціями, особливостями характеру.

Б. Джонсон загалом погоджується $з$ усталеною в тогочасній британській пресі, а потім й історіографії, точкою зору, що найістотнішими помилками Черчилля перших років Великої війни була вперта, і врешті, марна спроба втримати Антверпен, яка мала наслідком суттєві людські втрати, особливо 3 числа австралійських і новозеландських корпусів, а також Дарданельська операція, про яку ми вже згадували вище.

Втім Б. Джонсон не поділяє радикальних критиканських думок щодо невідповідності Черчилля займаній посаді Першого лорда Адміралтейства (с. 45 - 46). Натомість автор підкреслює особисту мужність і відвагу Вінстона у часи його перебування на Західному фронті як командира батальйону шотландських стрільців, який «36 раз бував на нічийній землі, іноді так близько до німецької лінії оборони, що чув голоси ворогів» (с. 73). Черчилль був, перш за все, стурбований збереженням життя особового складу і виступав перед командуванням з численними доповідними записками зі своїми тактичними міркуваннями, як максимально захистити бійців і полегшити їм виконання бойових завдань, причому деякі з його ідей були недоладними і «звучали відверто шалено» (с. 185). 
Але інші запропоновані Черчиллем нововведення, зокрема, броненосні «наземні кораблі», здатні долати траншеї з метою прориву оборони противника, мали воістину революційне значення і суттєво змінили хід подій на Західному фронті, підірвавши бойовий дух противника. Черчилль, наголошує Борис Джонсон, не лише висунув ідею створення танків, але й завдяки своїй наполегливості та впертості не дав занапастити і поховати іï у владних коридорах і армійських комітетах. На думку автора, ідея 3 танками - результат не лише тактичного і стратегічного мислення Вінстона, у ній - вся його природа, притаманний йому нюх до різноманітних винаходів та імпровізацій, невмирущий ентузіазм до технологічних інновацій (с. 185 - 195).

Ще до Першої світової війни у Черчилля з'явилася нав' язлива цікавість до польотів, вже тоді він усвідомив, що тендітні і крихкі тогочасні літаки одного дня стануть дужими і міцними і безцінно прислужаться обороноздатності Великої Британії (с. 65). 1917 року Вінстон Черчилль запропонував використовувати стратегічні удари великих груп танків, яким розчищатиме шлях бомбардувальна і штурмова авіація. I хоча наступного року і був сформований перший у світі танковий корпус, але повною мірою ця ідея була реалізована вже у Другій світовій війні, і далеко не одразу самими британцями. У перші повоєнні роки (1919 - 1921) саме В. Черчилль обійняв посади воєнного міністра і міністра авіації.

Іще до початку Першої світової війни Черчилль обговорював 3 експертами задум створення авіаносців. Як наслідок, через декілька років Британія першою у світі побудувала корабель такого типу. Черчилль створив військово-морську авіацію. Він наказав поставити на літаки, котрі до цього використовувалися тільки для розвідки, кулемети та пристрої для скидання торпед $\mathrm{i}$ бомб. А ще за ініціативою воєнного міністра було створено аероплан для злету з води і посадки на неї, якому сам Черчилль дав назву «гідролітак» (с. 65 - 66).

Як зазначає автор рецензованої книги, звичайно Черчилль, навіть при всій гостроті свого розуму, не зміг у ті часи правильно оцінити долю своїх революційних проєктів, які переросли у головні напрями військово-політичної стратегії майбутньої Другої світової війни. Нагадаємо, що у добу боротьби з нацизмом завдяки енергії Черчилля було створено першу у світі систему радіолокаційного контролю повітряного простору. Саме завдяки радіолокаторам у 1940 - 1941 роках було виграно авіаційну «битву за Британію» 3 нацистами. 
У своїй книзі Борис Джонсон постійно повертається до аналізу ідеологічних переконань Черчилля, підкреслює його затятий антикомунізм. Британський лідер болісно сприймав поширення у світі більшовицьких ідей, що підривали, в його розумінні, усталений світовий порядок, основою якого має бути демократія західного зразка, вільний ринок та приватна ініціатива. Він вороже ставився до тоталітарної форми правління і планової економіки, які шляхом нечуваного терору впроваджував у радянській комуністичній імперії Йосип Сталін. Після Адольфа Гітлера саме його Вінстон Черчилль вважав потенційним ворогом, що життєво загрожував усій західній цивілізації.

Слід зауважити, що Б. Джонсон свідомо кільканадцять разів використовує слово «цивілізація», щоб підкреслити масштаб впливу Черчилля на перебіг історії всього двадцятого століття.

Борис Джонсон цілком розділяє ставлення свого героя до Сталіна як до «тирана 3 мерехтінням в очах та абсолютним цинізмом і безжалісністю у душі» (с. 287) і його режиму. Аналізуючи зустрічі «Великої трійки» (лідерів СРСР, США та Великої Британії) під час Другої світової війни, автор наголошує, що на конференціях у Тегерані та особливо в Ялті британський прем'єр часто опинявся в ізоляції через позицію Франкліна Рузвельта, який через брак розуміння справжньої природи радянського тоталітарного режиму часто брав бік Й. Сталіна, який послідовно навязував програму радянського панування над Східною Європою.

«Аби зрозуміти відносну терпимість американців до росіян, зазначає Джонсон, - потрібно згадати, яким бачив світ Вашингтон у 1944 році і на початку 1945-го. Тихоокеанську війну жодним чином не можна було вважати завершеною. Від японців не очікувалося нічого, крім шаленого i самовбивчого опору. Населення Японії було виховано партизанською війною- аж до вміння битися списами. Американці знали, що зрештою перемогли б, проте боялися, попри володіння бомбою (атомноюЮ.Б., Л.П.), що втрати життів будуть жахливими. Вони сподівлися, що росіяни рішуче стануть на їхній бік» (с. 290 - 291). У результаті нехтування застереженнями $\mathrm{B}$. Черчилля вже наприкінці війни довелося спостерігати, як російський Ведмідь, самовдоволено посміхаючись, «пожирав Східну Європу» (с. 293).

Після несподіваного програшу парламентських виборів влітку 1945 р. Черчиллю спершу важко було впоратися з втратою свого статусу. «Світ був вражений, i до сьогодні людям важко збагнути, 
за що Черчилль міг дістати таку догану, - пише сьогоднішній лідер Консервативної партії. - Це явище не таке вже й дивне. Вибори виграють не на основі політичних досягнень, а на основі обіцянок на майбутнє у деякому сенсі його поразка $\mathrm{i}$ була його тріумфом. Він боровся за демократію для Британії, і ось вона: вигнання великого героя війни і лідера, не насильством, а завдяки мільйонам маленьких і ненав'язливих розчерків олівцем» (с. 283).

Однак, опинившись поза владою, колишній прем'єр не залишився на узбіччі світової політики. На запрошення американського Президента Гарі Трумана на початку березня 1946 р. Черчилль їде 3 приватним візитом до США, де у Вестмінстерському коледжі містечка Фултон (штат Міссурі) проголошує свою знамениту промову «М'язи світу», яка, на думку Б. Джонсона, «не схожа ні на що із політичного дискурсу сучасності» і була його натхненною візією майбутнього (с. 294, 297).

«У нинішніх діях Сталіна ми бачимо поведінку Гітлера в 1935 р., сказав Черчилль у промові «М'язи світу», - а тому Європі загрожує чергова окупація, цього разу вже радянська. Бо навіть після виснажливої війни СРСР не відмовився від своїх завойовницьких планів». Черчилль застерігав: придивившись уважно, можна помітити, що «від Щецина на Балтиці до Трієста на Адріатиці опустилася на континент «залізна завіса». По один бік iii - всі столиці древніх держав Центральної і Східної Свропи Варшава, Берлін, Прага, Відень, Будапешт, Белград, Бухарест, Софія. ... вони опинилися, як я це називаю, під радянською сферою впливу; всі вони тією чи іншою мірою потрапляють іще й під істотно зростаючий контроль Москви. Комуністичні партії, які були нечисленними у всіх цих країнах Східної Свропи, стали значно сильнішими... і всюди намагаються запровадити тоталітарний контроль» (с. 296). Черчилль пророче наголосив у Фултоні: «Росія зупиниться лише перед сильнішим».

Цей виступ і досі вважають мало не офіційним оголошенням західним світом «холодної війни» СРСР, забуваючи, що застереженню Черчилля передувала (місяцем раніше) промова Сталіна в Москві, сповнена неприхованої ворожості до усього «капіталістичного оточення».

Джонсон вказує на факт попереднього ознайомлення 3 текстом Фултонської промови Президента США Гарі Трумана, який після того, як здійнявся гамір у світовій пресі на своїй пресконференції публічно зрікся цього. Однак незабаром лідер США зрозумів правоту Черчилля i прийняв знамениту доктрину «політики стримування». 
Висока політична культура не дозволила В. Черчиллю виголосити таку епохального значення промову, не ознайомивши заздалегідь з іiі змістом чинного прем'єра Великої Британії Клемента Еттлі. Останній втім із «характерною для нього сумлінністю» відмовився на заклик членів парламенту від лейбористів зректися цього факту (с. 298).

«Фактор Черчилля» вплинув на всю повоєнну світову політику. Він відіграв важливу роль у створенні держави Ізраїль та в архітектурі сучасного Близького Сходу. Але чи не найбільше уваги Б. Джонсон приділяє ставленню В. Черчилля до питань євроінтеграції, що не дивно, адже у момент написання книги у країні вже точилися активні суперечки між єврофілами та євроскептиками, які зрештою закінчилися перемогою останніх і виходом Великої Британії з Свропейського Союзу (Брекзітом) у 2020 р.

Автор акцентує на невиправданій підозрілості і ворожості повоєнного лейбористського уряду до початкових кроків, спрямованих на європейську інтеграцію. Він показує нам Черчиллявізіонера, фундатора руху за об'єднання Свропи (с. 306 - 313). Джонсон твердо переконаний, що якби у цей час прем'єрміністром був В. Черчилль, він погодився би, принаймні, на участь в обговоренні проєкту Р. Шумана. Він висував вагомі аргументи на користь участі Британії у процесах європейської інтеграції у багатьох промовах повоєнного часу, які наводить автор. Черчилль апелював до питань безпеки, суверенності, намагався переконати слухачів у тому, що в євроінтеграції зрештою зацікавлені і США. Але парадокс був у тому, пише Б. Джонсон, що євроскептики 3 таким самим успіхом можуть тицяти у тексти Черчилля, хоча інколи для підсилення і трішечки перекручуючи цитати, і знаходити там інше бачення місця Британії в об'єднаній Європі (с. 314).

Сам Черчилль не робив трагедії з того, що через помилку лейбористів (а саме так він вважав), Велика Британія залишилася поза Європейською економічною спільнотою. Навпаки, він «з батьківською гордістю спостерігав за розробкою планів спільного ринкового простору (y Західній Європі - Ю.Б., Л.П.). Адже це була його ідея - звести ці країни разом, поєднати їх так нерозривно, щоби вони більше ніколи не пішли шляхом війни» (с. 317). I цей задум, як майже всі ідеї великого британця, теж став прикладом яскравого успіху.

Цікавим є розділ книги Б. Джонсона, де аналізується сучасне побутування спадщини В. Черчилля у Британії. Зокрема, йдеться 
про використання його імені і прізвища у найрізноманітніші способи, і по-суті, створення нового бренду «Черчилль».

У заключному розділі «Фактор Черчилля» Б. Джонсон підкреслює, що Вінстон Черчилль був не лише політиком свого часу, він і сьогодні надихає багатьох своїми вчинками, своєю рішучістю, безкомпромісністю, нарешті - своїми промовами, книгами і картинами. «...Я твердо підтримую позицію тих, хто вважає, що не існувало нікого, навіть віддалено схожого на нього, ані до того, ані опісля» (с. 365).

Крізь книгу Б. Джонсона наскрізною ниткою проходить не лише його захоплення персоною В. Черчилля. Автор як політик високого рангу мимоволі, а може й навмисне, намагається крізь призму біографії свого героя збагнути власну діяльність. Він зізнається: «Правда у тому, що, хоч мені й любо писати та думати про Вінстона Черчилля, старий може трохи й присоромити мене. Покваплюся зізнатись, робота над його темою завжди $\epsilon$ неймовірним задоволенням - проте, коли намагаєшся дати справедливу оцінку його життю, принизливо усвідомлюєш, що прикутий до його генія, генія неймовірної енергії та плодючості» (с. 359).

Книга не позбавлена незначних недоліків. Інколи автор вдається до надто розлогих цитувань. Хоча структура книги є добре продуманою і відповідає задуму Бориса Джонсона, при іiі прочитанні часом хотілося більшої хронологічної послідовності у викладі подій. Джонсон не оминув окремих усталених кліше, характерних для англо-американської історіографії, зокрема щодо СРСР, але вони, очевидно, пов'язані і 3 особистими політичними переконаннями автора.

Підсумовуючи, зазначимо, що книга Бориса Джонсона - це, безумовно, чудовий аналіз особи, життя i діяльності Вінстона Черчилля, зроблений у першу чергу з позиції британця і британського політика. Любов і повагу до героя своєї оповіді автор не лише проносить до останніх сторінок, а й передає ії читачеві, причому робить це щиро і без фальші.

Із дослідження читачі почерпнуть для себе велику кількість маловідомих фактів про В. Черчилля, побачать його і як політика, і як людину, i все це на тлі найдоленосніших для світу подій двадцятого століття. Все це робить книгу Бориса Джонсона не лише захопливим, а й пізнавальним і корисним читанням.

Рекомендуємо книгу Бориса Джонсона студентам та курсантам вищих навчальних закладів України, які вивчають курси «Всесвітня історія», «Історія озброєння і військової техніки», «Історія міжнародних відносин» тощо, усім хто цікавиться минулим людства. 